\title{
Police, clans and cash in Somalia
}

\author{
By \\ Alice Hills
}

\begin{abstract}
This article explores the ways in which emergent police forces in conflict-affected Southern societies are shaped by cultural practices operating through social phenomena. It uses the record of the prototypical police forces found in the Somali cities of Kismayo and Baidoa, 2014-2017, to explore the ways in which culture, power relations and local realities - in this case, clan-based calculations, Somali and international politics, and physical insecurity - influence police development. It draws on the cities' experience of a donor-funded "basic policing" programme to identify the motivating forces shaping police evolution in a society familiar with many aspects of conventional policing operations and vocabulary but positioned at the opposite end of the technical and institutional spectrum to those shaping police studies' canonical literature.
\end{abstract}

Keywords: Clans, cultural practices, police, recruitment, stipends, Somalia

Hills, Alice: "Police, clans and cash in Somalia", Culture Unbound, Volume13, issue 3, 2021. Published by Linköping University Electronic Press: http://www.cultureunbound.ep.liu.se 


\section{Culture Unbound}

Journal of Current Cultural Research

This article explores the ways in which police forces emerging in volatile post-conflict Southern societies with low literacy rates are affected by cultural practices operating through social phenomena. It uses the implementation of a three-year donor-supported police project introduced into the Somali cities of Kismayo and Baidoa in 2014 to explore the ways in which culture, power relations and local realities - in this case, clan-based calculations, Somali and donor politics, and chronic insecurity - affect the meaning, development and implementation of police programmes.

Based on interviews with senior international and Somali advisers and analysts in Mogadishu, Nairobi and London in 2016 and 2019, its focus on the cultural practices and values influencing the organisational development of formal policing permits exploration of the dynamics (i.e. the issues producing movement and change) of emergent police forces in an otherwise inaccessible environment. ${ }^{1}$ Drawing on Grindle's discussion of good-enough governance as "the minimal conditions of governance necessary to allow political and economic development to occur" (Grindle 2007: 554), though using the term descriptively rather than technically, it identifies the impact of Somali preferences and practices on the minimum requirements necessary for the political and social phenomenon that is internationally acceptable formal policing. The article's basic assumption is that policing is a process of interaction within specific environments of interest and power (Findlay and Zvekić 1993: 5). Further, policing is not only a product of its environment: it shapes its political and social development in a fundamental manner. Thus, the key cultural practices, behaviours and norms affecting the selection and deployment of Somali police officers ${ }^{2}$ are clan-related; clan affiliation, which is regulated by Somali customary law or xeer, is the main indicator of identity within the Somali nation and effectively determines access to policing provision (Luling 2006, Gundel 2009). Nevertheless, clan is itself a flexible political and social tool, and clan relationships are often a mask for elite economic, political and ideological interests (World Bank and UNSOM 2017: 17, Home Office 2019: 13, 14). In other words, clan helps to illustrate the ways in which the behaviour, preferences and values shared by most Somalis (i.e., Somali cultural practices) are externalised and become events or occurrences capable of influencing group or individual conventions, norms and organisations (i.e., social phenomena). Although the dynamics at play are opaque and inaccessible to most non-Somalis, Kismayo and Baidoa's experience nevertheless helps to provide the granular detail needed for meaningful analysis.

The discussion that follows considers, first, the challenges of identifying the factors shaping prototypical or quintessential forms of police forces. To explore the explanatory value of this approach it notes, second, the contextual details of Kismayo and Baidoa's police before, third, identifying the minimal requirements 


\section{Culture Unbound}

Journal of Current Cultural Research

needed to meet local expectations. These are reflected in section four, which pays special attention to three issues expressing the power relations, cultural preferences and physical insecurity at the heart of Somali policing: recruitment, stipends and retention. The discussion concludes that while the formal structures of prototypical police forces indicate the political expectations of their most influential (and typically international) advocates, the day-to-day development and implementation of such forces is influenced primarily by local cultural preferences operating through social phenomena.

\section{Policing reflects cultural preferences}

It has long been accepted that the social order reproduced by the police reflects the needs and expectations of the society that permits its operation (Marenin 1985). Further, much is known about the technically sophisticated policing found in rich industrialised societies such as the USA, UK, Japan and Australia, each of which exports its preferred style of policing to conflict-affected societies (Bayley 1990, Chan 1997, Reiner 2015). Yet little is known about the dynamics of formal policing in countries where state and police institutions are a facade, and opaque and informal decision making is favoured over institutional clarity and procedural predictability, even though their experience offers insight into the police's evolution towards professionalism and institution building (Giustozzi and Isaqzadeh 2013: 1). In other words, there is a gap between the canonical touchstones of policing and those found in fragile Southern countries: in this case, Somalia.

Dedicated to facilitating the technical and political standards associated with "professional" policing, the international communities' preferred approach relies on multi-agency co-operation, service and community-oriented policing, which is presented and justified in terms of technical standards or, more commonly, democratic norms and values such as accountability and gender equality. A case in point is the United Nations Development Programme (UNDP)'s focus on policing strategies designed to 'improve access to inclusive, equitable and accountable forms of security and protection for all Somalis' (UNDP 2019). The result is that donors import international models and practices while neglecting the realities of everyday Somali life, downplaying the extent to which security provision is linked to clan-based calculations, business opportunities, political influence, and resources such as cash and land (de Waal 2015: 109-129).

Although police studies now include ethnographically informed accounts of police forces in relatively functional states such as Niger and Nigeria, little attention is paid to formal policing in societies in which state and police institutions are a facade (contrast Beek et al. 2017). One result is that the billions of euros, sterling and US dollars - and Turkish lira and Japanese yen - spent on police-related 


\section{Culture Unbound}

projects in Somalia have achieved little of practical or analytic value. It could not be otherwise when donors do not know how Somali police understand their role or spend their day, let alone understand the ways in which international and local approaches converge or diverge. More fundamentally, little is known about the ways in which police development and the power networks associated with emergent security forces and their occupational culture relate to social practices. One way to address this is to explore the empirical foundations and defining traits of specific examples of Somali policing.

Somalia's experience is extreme, so it provides a readily comprehensible limiting case and Kismayo and Baidoa's experience makes the fundamental or residual elements of formal policing visible. Its experience offers generic and granular details that help to illustrate the energising and relational forces influencing emergent police while reminding us that in much of the world policing provision (and residents' engagement with it) owes little to formal structures and actors and everything to power politics, local preferences, contingencies and legacy issues, i.e., to cultural practices expressed through social phenomena.

\section{Basic policing's explanatory value}

At first glance, the 'Re-establishing basic policing programme' (RBPP) introduced in Kismayo and Baidoa is a conventional donor response to a standard Somali request: it was developed and supported by the UK's Department for International Development (DFID) in response to an official request from Somalia's president in 2012 for UK support for police stipends. The combination of international consensus on Somalia's strategic significance and the president's use of the language of state-building and democratisation ensured that RBPP received political permission and funding at the Somalia conference held in London in May 2013 when $£ 8$ million was pledged to the Mogadishu-based Federal Government of Somalia (FGS)'s security, justice and armed forces plan. This was reconfirmed at the European Union (EU)'s Somalia Conference in Brussels in September. The Brussels talks focused on the role of the FGS and its Somali Police Force (SPF), but also addressed the need to improve security in three cities recovered from the militant group al Shabaab in 2012: Kismayo in the federal member state of Jubaland, Baidoa in South West State and Beledweyne in Hiraan (approximately 520 kilometres to the south of Mogadishu, and 230 and 342 kilometres to its north-west, respectively). This was internationally acceptable because the discussions included agreement on a "New Police Model" setting out a framework for governing and delivering policing in Somalia's federal system (UNSOM 2017). Working with the African Union Mission in Somalia (AMISOM) and Africa's Intergovernmental Authority on Development (IGAD), donors (including the United Nations Assistance Mission in Somalia, UNSOM) promoted the negotiation of memoranda 


\section{Culture Unbound}

of understanding between the FGS and Jubaland and South West State on the establishment of the federal member states' police forces and their relations with the federal government's force. This included developing what became known as RBPP, which was intended to enable 1,800 recruits to carry out basic police functions after completing a 12-week course provided by AMISOM. The programme was understood as comprising two components: Stipend delivery and a human resource system managed by the UN’s Office for Project Services, UNOPS ( $£ 6.3 \mathrm{~m})$, and third-party monitoring of the police's performance, behaviour and respect for human rights by Sahan, a Nairobi-based consultancy $(£ 1.8 \mathrm{~m})$. Monitoring was a prerequisite for Jubaland to be eligible for the payment of stipends.

The original DFID call for RBPP referred to developing a baseline for analysing how Somalia's formal police and justice sector operated while identifying potential indicators for measuring future progress (DFID 2016). In the event, RBPP was presented in terms of it achieving objectives measured in precise numbers, democratic values and political goals: it was to assist Somali authorities in recruiting up to 1,860 officers who would improve security for Somali citizens (particularly women and girls) and enable the re-establishment of essential services such as health and education while facilitating AMISOM's exit and the handover of basic responsibilities to Somali security institutions. It is not clear who in DFID was responsible for this agenda, but it was quickly agreed that RBPP was to deliver civilian policing and be rolled out in liberated and accessible areas across southern and central Somalia, starting with Kismayo and Baidoa (DFID strategic adviser, London, 10 June 2019). The high reputational and financial risks associated with this were acknowledged but regarded as politically acceptable (Devtracker 2015: 2).

The RBPP was implemented in 2014 and operated successfully as a stand-alone programme until 2017 when it merged with the UK's new Security and Justice Programme to form part of a component addressing "Expanding, training, equipping and providing infrastructure for the police" It then moved from being a bilateral project to becoming part of a joint policing, security and justice programme managed by UNOPS and funded by, amongst others, the EU (which allocated $€ 80 \mathrm{~m}$ ), Germany, Italy, Denmark, the UK, Japan, Turkey and the USA which provided training in criminal investigation and counterterrorism.

The programme's success owed much to the practical manner in which international and local approaches to policing provision were accommodated. The decision making associated with it may have been unclear, but details were handled pragmatically; neither side made unreasonable demands and implementation remained a simple flexible compromise. DFID reports might state that RBPP was a contribution to building a more inclusive political settlement while increasing the public support necessary for developing a social contract between politicians 


\section{Culture Unbound}

and the populace, but in practice DFID and AMISOM handled their involvement lightly, allowing the clan-related concerns of elders and local politicians to influence the selection, vetting and recruitment processes. Similarly, DFID's insistence that Kismayo and Baidoa's liberation from al Shabaab required RBPP to first develop an elementary police doctrine capable of promoting good practice while meeting Somalia's security challenges was ignored by the cities' militia-like police (DFID 2017: 7).

The RBPP adds to our understanding of the influence of cultural practices and values on police development in three important ways. First, its recruitment and vetting phases illustrate the criteria needed to satisfy local expectations, the reasons why would-be officers apply, and what they expect. Second, RBPP emphasises that the critical factor affecting emergent police forces is the payment of stipends; stipends are a temporary measure that buys a modicum of loyalty, and this is as, if not more important than their value as a cultural signifier of Somali avarice or poverty, or a signal of the political and open-ended nature of the international community's commitment to unitary statehood, and the nature of its engagement with Somalia's federal governments. Third, RBPP's record suggests that policing based on officers' physical presence has greater potential for improving police-community relations than the value-laden approach associated with conventional forms of community-based policing.

\section{Priorities in Kismayo and Baidoa}

The documentation for RBPP makes no reference to DFID commissioning surveys of residents' views on the proposed police. Despite this, much can be deduced about what people wanted and the minimal requirements they thought necessary for stabilisation. Specifically, information on the role of police before and after 2014 is available from the Hargeisa-based Observatory on Conflict and Violence Prevention (OCVP), which in 2015 conducted a series of surveys using standardised questionnaires and indicators evaluating community perceptions of the deployment and performance of the various formal and informal security providers. Further, despite Kismayo and Baidoa's different geographical location, population size and security levels (Kismayo was regarded as safer than Baidoa), police in both cities shared sufficient commonalities to make the requirements for good enough policing clear (for district profiles see OCVP 2015a, 2015b). OCVP's findings can be supplemented by the surveys conducted by Sahan's Somali researchers, thereby providing a record of RBPP's key features as they appeared to residents. ${ }^{3}$

Kismayo is a port city in Somalia's southern Lower Juba province and the commercial capital of the autonomous Jubaland region, which is a part of the Federal Republic of Somalia. Its population of some 234,850 (which includes 


\section{Culture Unbound}

more than 30 sub-clans) makes it the third largest city in Somalia. Its combination of port revenues, relatively fertile soils, grazing grounds and marine resources also make it a valuable prize for al Shabaab, which controlled it until 2012, when it was driven out of the city by an alliance between the Somali National Army (SNA) and AMISOM under a UN mandate. In 2013, the Juba Interim Administration (which was established in 2010), was officially recognised as the government of Jubaland under a national reconciliation agreement, and its courts resumed operations in December 2014 (OCVP 2016: 2-3). The 230,000 residents of Baidoa, capital of the Bay region and one of Somalia's main economic centres, also came from multiple clan and ethnic backgrounds. But Baidoa district had been very badly affected by war in the early 1990s and in 2013 was patrolled at night by AMISOM's Quick Response Forces, which acted as a standby in the event of an attack by al Shabaab. And despite their relative stability, both towns experienced - and continue to experience - attacks; in July 2019, 26 were killed when al Shabaab attacked a Kismayo hotel (Reuters 2019).

The priority for both cities was a basic police force capable of facilitating stabilisation, rather than health or education services. Indeed, OCVP's representative range of respondents regarded security as the cornerstone of development, and were particularly worried by the presence of al-Shabaab, clanbased fighting, revenge attacks, and violent land and family disputes exacerbated by the involvement of unemployed youths (for the representative nature of respondents and their views on police see, e.g., OCVP 2015a: iii, 6-14). Kismayo was considered to be the safer of the two cities but, even there, residents identified power struggles as the main cause of conflict, with fighting between the security forces and al-Shabaab a major cause of concern; significantly, al-Shabaab was able to exploit clannism and ruthlessly impose justice while using the revenue provided by the religious duty to give alms and charity to pay its soldiers and operatives well and regularly (DefenceWeb 2017). Although not mentioned by respondents, social cohesion may have been adversely affected by rapid urbanisation, the expansion of sprawling low-density developments and an increase in the number of IDP sites (OCVP 2015b: xi, UN Habitat 2017). In the first two weeks of July 2019, drought drove more than 5,000 internally displaced persons to Baidoa town, adding to the existing 323,000 (OCHA 2019).

In 2014, security was formally delivered by a combination of Somalia's police and military forces with support from AMISOM troops and the National Intelligence Security Agency (NISA) - and, as OCVP's surveys make clear, Kismayo and Baidoa's residents referred to security providers and security provision, rather than to police or policing. In the aftermath of al Shabaab's expulsion, powerful clans in the new states had quickly created agencies modelled on former president Barre's intelligence agency, which was by far that era's 


\section{Culture Unbound}

Journal of Current Cultural Research

strongest institution (Ahmad 2013), so it comes as no surprise that Jubaland's Intelligence Agency was also active. Each of the providers had different mandates and lines of authority and communication and operated independently though residents supported them through committees such as neighbourhood watch groups (madani) while the state's role was often undertaken by traditional leaders such as clan elders and sheikhs (religious leaders), whom the majority of OCVP's respondents trusted more than the police (OCVP 2015a: 6-14).

Despite this, the police were the preferred provider for many OCVP respondents. In the year leading up to 2015's surveys, respondents in Kismayo reported an increase in cases reported to the city's small police force, especially with regard to civil matters such as trespass and family or business disputes, as well as to petty crimes such as theft and domestic violence, while the number of serious crimes reported to the police almost equalled that reported to traditional elders (intelligence issues and al Shabaab are dealt with by intelligence or military forces). The reasons for this are unclear but an OCVP youth focus group said that relevant factors included the type of case, level of confidence in the security provider, expected outcome and complainants' financial resources (OCVP 2016: 17). Respondents in Baidoa also identified the police as the most trusted security provider even as informal providers such as traditional elders and religious leaders were widely regarded as legitimate decision makers, especially for dealing with civil matters or petty crime (OCVP 2015b: xi).

Although 52 per cent of OCVP's respondents in Baidoa declared their satisfaction with the police, insisting that they trusted it to some extent, they were aware of the obstacles undermining the police's performance. As in Kismayo, these included corrupt officials, inadequate resources (including vehicles and fuel), insufficient numbers of officers and police stations (in 2015 there were two stations in Baidoa and one in Kismayo), and the authorities' failure to provide officers with "fair compensation for doing a very risky job" (OCVP 2015a: iii, OCVP 2015b: 5-14). Addressing such issues would, it was thought, offset the unwillingness of suitable recruits to join the police and, importantly, lessen dependence on AMISOM troops (particularly the Kenyans assisting the SNA to secure Kismayo), and restore something akin to normalcy. Respondents did not think that the police's performance had worsened in 2014, but (and this is significant in the light of the popularity of policing by presence) it is clear from their comments that the absence of uniforms or an official logo meant that it was difficult to separate police from militants or militia; only the elderly officers who had served during the Barre era could distinguish easily between the two (OCVP 2015a: 8). But there were no easy answers because Somalia's formal and informal actors lack the functional divisions that define responsibilities in more settled societies, and typically play multiple and overlapping roles (World Bank 2017: 40). 


\section{Culture Unbound}

\section{Policing's minimal requirements}

In contrast to most donor projects in Somalia, RBPP addressed the minimal requirements needed for internationally acceptable everyday policing; it concentrated on locally prioritised issues while recognising that the initial focus on recruitment and basic training would soon need to shift towards improving performance and police-community relations. Instead of focusing on the organisational structure, capacity and institutional development of the police at state level, it addressed issues, such as clan representation and stipends, that directly affected the officers on whom street-level policing depended. RBPP's documentation allows us to identify not only the factors influencing this, but also the real needs of internationally supported but locally driven development. And they are few in number. The initial priority was recruitment because numbers matter and the type of applicant selected influences the ways in which a police officer is perceived and operates. But stipends are as important because they help to buy the loyalty on which forces depend. In addition, they offer insight into local perspectives on three fundamental, but otherwise inaccessible, issues: the nature, purpose and role of the police. In practice two questions dominated RBPP's agenda: what was affordable, and how best to address Somalia's violence and cultural complexity (World Bank 2017: xi).

\section{Function matters more than form}

The purpose of the police matters because, in policing as in architecture and industrial design, form follows function and prevailing norms, rather than, as donors might wish, function following form; in other words, what a police force does is more significant than how it is organized or presented. Even so, the purpose of Somalia's police is ambiguous and contradictory tendencies abound. Blurred functional divisions between police and militia are one such issue, not least because policing styles are influenced by Somalia's chronic violence which is thought to be clan related. But this is inaccurate; while clan identity is an important factor, it is not the element driving conflict and is often used to mask elite interests (World Bank 2017: 17). Further, policing provision is part of the business of politics for Somalis (de Waal 2015) and of stabilisation for donors, and, while local and international goals and values are often incompatible, especially on issues such as human security and gender equality, the resources brought by internationals ensures donors a certain influence. At the same time, many older Somalis are acquainted with the vocabulary of international policing; Somalia had a conventionally organised police force in the three decades after independence in 1960 so many are familiar with the notion of a state-based police even if civil war meant that it was not until the early 2000s that today's SPF (re)emerged in Mogadishu and Puntland. The result is that rather than rejecting international 


\section{Culture Unbound}

Journal of Current Cultural Research

models, Somali police and politicians typically subvert, undermine, ignore or mimic the processes and values promoted by their international sponsors in order to gain specific goals (Bhabha 1994:121-122).

The SPF is widely recognised as the legitimate descendent of that original force, celebrating its 78th anniversary in 2021, whereas Kismayo and Baidoa's official police forces were not created until 2015 when the federal states were recognised. Perhaps because of this, residents value their state-based police force (security analyst, Nairobi, 15 April 2019). Some take pride in it because it gives credibility to their new state while others value it as a source of employment or, better still, revenue; the US $\$ 6,000$ brought into Kismayo annually by new recruits (each of whom receives $\$ 100$ a month) represents a major bonus. It is therefore important to ask what sort of police residents wanted, and what they thought police should or should not do. This matters more than the police's organisational structure, not least because Kismayo and Baidoa do not yet have functioning state institutions; the police are arranged along clan lines, politicians have personal militia, and residents rely on their clan to address policing issues (Peace Direct 2019).

Like their peers in Kismayo, the authorities in Baidoa wanted the police to be "trained, respectful, and close to the community" (Sahan 2015: 6). How, then, did successful recruits behave? How were they deployed? How did they understand their job? Unfortunately, it is not possible to offer detailed answers because little is known about Somali police culture and everyday business. International police advisers may have some understanding of Somali attitudes, but they are rarely in post for long and most base their assessment on the processes and norms of their home country. Additionally, the nature of Somalia's languages and culture ensures that most international organisations rely for interpretation on Somali cultural advisers, many of whom were formerly part of the Somali diaspora and lack police experience. Fortunately, the surveys conducted by OCVP and Sahan's Somali researchers suggest tentative answers.

Despite donors' advocacy of trust-based police-community partnerships, the picture that emerges in 2014 is one in which officers spend most of their time in stations or posts in potentially dangerous localities, emerging only to man checkpoints or conduct some form of operation or shakedown. Indeed, many officers were too old or unfit to do otherwise; as Baidoa's police commissioner told OCVP in 2015, of the city's 70 officers, 20 spent their days in one of the city's two police stations because they were too old to take part in operations or patrolling (OCVP 2015b: 14). It suggests, too, that there is a Somali equivalent to the distinctive "canteen culture" shared by many officers in UK police stations (Waddington 1999 ). Perhaps because of this, residents rate the police's physical presence more highly than their technical skills or response rates. And there is a notable police presence in Kismayo and Baidoa. This may not tell us much 


\section{Culture Unbound}

Journal of Current Cultural Research

about the nature of police culture, but it makes aspects of everyday police business visible. By 2015, police activities included traffic duty, checkpoint security and static guard duty at government facilities (PCR 2017: 14); foot patrols and the presence of a substantial number of police during the day and, occasionally, at night were particularly popular with residents in the urban core while some units were deployed to outposts surrounding the cities in order to reinforce the authority of the local government. The police presence might have been limited but, as studies of preventive patrol in Minneapolis found, even in the USA, the optimal length for patrol stops is 11 to 15 minutes (Koper 1995). Further, and despite substantial anecdotal and circumstantial evidence to suggest that few officers value police-community relations as such, let alone seek to provide a service, there are cases of police and residents collaborating to share information and manage insecurity. In Kismayo, community members who have received security training from the police collect and share information with officers while checkpoints on roads leading to Kismayo town keep a list of community elders who can be called on to resolve issues as they arise (elders are often asked to vouch for people or to clarify incidents) (Peace Direct 2019: 22). Nevertheless, the police's role is limited and most of the crimes and incidents that might be expected to involve officers are resolved by clan elders and customary law. Some crimes are reported to the police, but most are not because residents are afraid of reprisals by the accused. Also, the absence of a formal functioning justice system means that most suspects are released without charge.

These details help to indicate the extent to which Somali police culture is affected by clannism, poverty and violence which can only be addressed by specialised units able to act decisively. Indeed, many of Sahan's respondents said that they would prefer a fighting force capable of taking on, e.g., al Shabaab, which continues to control several major towns in Jubaland (security analyst, Nairobi, 15 April 2019, Somali Affairs 2019). It is not by accident that police in Kismayo and Baidoa are commonly described as security forces and their formal command structures remain aligned with those of the former Somali military. It also means that distinguishing between police and militia is not a priority because the police is essentially a militia; the two are not separate functionally, politically or culturally, and, while there may be 600 police in Kismayo, there are 5,000 militia (senior UK adviser, Nairobi, 16 April 2019). The expectations of residents and officers are accordingly low. Residents do not complain when police stay inside their guard houses, fail to record custody cases, and ignore evidence. Meanwhile AMISOM's provision of six weeks of basic drill-related training is accepted because it provides shoes, clothes (i.e., uniforms) and regular wages; $\$ 100$ is paid into the account of those who are present and behave. 


\section{Culture Unbound}

\section{Visibility is as important as accessibility}

The key to basic policing in Kismayo and Baidoa lies in what is best described as policing by presence. To its credit, DFID understood that policing needed "to be considered in terms of providing a visible security presence, that behaves and performs in a manner which builds confidence [sic] of communities" (PCR, 2017: 7). In practice, presence, accessibility and reassurance were mutually reinforcing, and residents found the results understandable, acceptable and reassuring in a way that donors' conventional community-oriented policing was not. Hence OCVP took the high level of awareness of the proximity of police stations reported in Baidoa as an indicator of police presence; a majority (86\%) of respondents were sufficiently aware of the police to say that they lived less than forty minutes away from their closest station (OCVP 2015b: 13-14). Indeed, accessibility was one of the main reasons why OCVP and Sahan's respondents chose the police as their preferred security provider.

The police's presence was evident in three main ways (security analyst, Nairobi, 15 April 2019, PCR 2017: 14). First, police were visible at checkpoints, which could be at an airport, a busy intersection, a location identified by elders, or traffic control points, especially in Baidoa, where abuse and beatings often happened when tuk-tuks (three-wheeled taxis) failed to stop or drivers misunderstood instructions. Patrol groups of five or six officers were also seen, sometimes in pick-ups donated by Japan (this was more common in Kismayo). Second, both cities had a donor-funded police headquarters and main police station. As the safer of the two, Kismayo also had several one-man posts whereas Baidoa had a police representative in each area even though this could leave the individual concerned alone in a dangerous locality. Nevertheless, accessibility to officers did not necessarily improve police-community relations, especially in Baidoa where OCVP found that an individual's status and familiarity with officers was thought to have the greatest influence on police responses (OCVP 2015b: 9, compare Owen and Cooper-Knock 2015); those without connections were unwilling to report crime to the police because they feared being labelled as an informant or accused of causing the incident. This suggests that, in reality, the success of policing by presence, static or mobile, may have been fortuitous, owing more to Somali realities than to RBPP, let alone to DFID's advisers. For residents wanted to develop personal links with known officers at known locations whereas DFID saw the police's presence on the streets and in stations as a means to not only develop links with international organisations engaged in Somali police development, but also to ensure security sector reform, and the rule of law and access to justice more broadly (senior international adviser, Nairobi, 16 April 2019). ${ }^{4}$ 


\section{Culture Unbound}

\section{Three critical issues}

The RBPP's record indicates the ways in which cultural norms operating through social phenomena affected the political legitimacy of the new federal member states, the desirability of the resources associated with its delivery, and the pragmatic response of residents to the new police. The disadvantage of our not knowing the detailed negotiations accompanying its implementation is offset by the insights RBPP offered into the development of state-based forces in a patriarchal and legally plural environment in which the group is more important than the individual. The RBPP offers opportunities to explore, empirically and analytically, the motivating forces affecting police development in a society familiar with conventional policing operations and vocabulary but positioned at the opposite end of the technical and institutional spectrum to those shaping police studies' canonical literature.

Three linked issues express the impact of cultural rules and expectations on the emergent forces: recruitment, reward (i.e., stipends) and retention. Recruitment comes first because the type of applicant selected influences the way in which a force operates, develops and is perceived. It, together with retention, emphasises the criticality of local power relations and group interests in clan or tribe-based security forces. But the resources associated with recruitment and deployment mean that neither can be considered in isolation from clan interests. Attempts to loosen the link have to date failed.

\section{Recruitment}

Recruitment was the first step in implementing RBPP, so selection and vetting were a priority. The process was conventional, but it provides insight into the procedural points at which Somali and donor expectations met. The second phase of vetting and selection for the Jubaland State of Somalia (JS) police force conducted in Kismayo, 16-25 May 2016, is representative of the process. ${ }^{5}$

The initial responsibility for determining the composition and conduct of the new police lay with the JS acting with the support and advice of external organisations such as the African Union Police (AUPOL) which worked alongside JS authorities to vet and select 200 recruits. Some 250 members of Jubaland's existing security forces applied (a significant proportion of whom were probably Ogaden, a large sub-clan of the Darood family), and 140 were selected for the second police training course, but their overall quality was low. Perhaps because of this an open call was made using public advertisements around Kismayo town. This resulted in 200 applications from the public, 70 of whom were chosen to join the exercise. Although some of those chosen may have been al Shabaab sympathisers, the open call ensured that most of Jubaland's clans were represented even if the Ogaden's 33\% share ensured its dominance (it had been 50\% in the first 


\section{Culture Unbound}

Journal of Current Cultural Research

phase). But this was reasonable because officers need to be representative of the communities they come from if they are to have the networks and local knowledge required for effective policing.

Two findings deserve note. First, although Somalia's police are not dependent on the existence of a police institution, the RBPP assumed that bureaucratic structures existed: applications were to be submitted to Jubaland's ministry of interior through the police commissioner's office. Second, pragmatism was as important as formal selection criteria. Candidates were vetted by a joint Jubaland and AMISOM/AUPOL team of 18 individuals whose procedures included profiling based on personal information (including clan and sub-clan affiliation), a medical examination, a fitness test, and a written exam. Although many applicants were ineligible because they were unfit, illiterate (many did not have the high school education listed in the advertisement) or from the wrong clan, clan representation usually superseded everything else, including literacy; $40 \%$ of those selected were illiterate. Thus, many of the successful Jareer candidates interviewed by Sahan in Kismayo had not completed their high school education but were accepted because their inclusion helped to ensure community participation. But there were exceptions to the rule as when a significant proportion of the former police from the Ogaden who had failed the vetting and screening exercise were dismissed. Similar considerations influenced the process in Baidoa. Residents often told Sahan's assessors that clan calculations should be removed from decision-making on the police, but it is not clear what could have replaced it; literacy levels were low, conventional forms of discipline were unwelcome, and social cohesion was sustained by elders and place of origin (i.e., clan).

Although training is not strictly part of recruitment or retention, it too influences (and expresses) attitudes to being a police officer. Working with UNOPS and AMISOM, RBPP funded the establishment of basic training facilities for 600 recruits in Kismayo and 600 in Baidoa. But judging from the experience of international advisers training SNA soldiers in basic logistics, many recruits had unrealistic expectations of what was expected of them. Thus, Steigman found that clan-based calculations affected every aspect of SNA life; relationships amongst his trainees were based on power rather than on goodwill or professional recognition, and any form of disciplinary procedure (e.g., weapons searches) was resented (Steigman, 2018). ${ }^{6}$

Comparable problems were evident at RBPP training camps. Recruits who failed the initial sift were upset and disrespectful, though the likelihood of their being targeted by al Shabaab meant that they still spent six months (unpaid) at the camp (Sahan 2017: 27). Meanwhile, disciplinary issues reoccurred during training because there were no accountability or performance monitoring measures. Just as the Somali co-ordinators Steigman worked with were unsure as to whether 


\section{Culture Unbound}

trainees were actually in the SNA, so many police commanders were unable to say where a specific officer was on any given day; weekly attendance parades were held at the police headquarters in Baidoa, but there were no repercussions for those who failed to turn up.

\section{Reward}

Recruitment offers insight into the dynamics of policing, but stipends are arguably more significant because they help to buy loyalty and ensure retention, i.e., they illustrate local perspectives on the nature, purpose and role of the police. They also show how donors accommodate Somali expectations and demands for, unlike recruitment and deployment which often run regardless of external influences, the payment of stipends depends on donors.

Three features are noteworthy. First, stipends are a bureaucratic measure that conforms to donors' political culture. Thus, between April 2013, when the UK's foreign secretary and development secretary approved outline plans for DFID to provide $£ 8$ million for the support of police stipends, and the end of 2016, RBPP spent precisely $£ 6,240,791.47$ (PCR 2017). Comparable processes shaped donor-Somali relations, as when a co-financing agreement was signed between DFID and the Federal Member State authority in Jubaland whereby the Jubaland authorities agreed to pay officers $\$ 100$ directly each month, with DFID authorising UNOPS to make the donor-funded payment once confirmation of receipt was received.

Second, stipends are indicative of the cultural tensions that exist when top-down external policies and processes meet the interests of local actors: stipends dominated meetings between donors and Somali officials, absorbing time and energy, and creating dependency. Delivery was made easier in Kismayo and Baidoa by the introduction in 2015 of an electronic system that delivers money to individual's mobile phones or bank accounts (registered and trained recruits in Baidoa receive a monthly electronic stipend), but there is no way of managing Somalis' unrealistic expectations.

Third, in theory, stipends are a signal of the international communities' commitment to providing an environment in which new forces can develop and stabilise, but in practice they are temporary wages that may buy the loyalty needed for retention and successful operations. This matters because many officers are militiamen, and desertion or unauthorised leave is common. Each trained officer receives a monthly stipend according to rank: constables to captains receive US\$ 100 , majors to colonels $\$ 150$, brigadier generals $\$ 300$ and major generals $\$ 900$ (DFID 2015: 2). But this is not enough to prevent desertion or corruption in a country that Transparency International ranks as the most corrupt in the world (Transparency International 2019). In Baidoa, for example, the leadership of the 


\section{Culture Unbound}

police rests with federal police officers who are paid irregularly by the federal government. Inevitably, differences in pay structures lead to friction between the police and their supervisors and can result in regional police collecting money at illegal checkpoints on behalf of the police leadership. Kismayo presented a relatively benign environment in which to implement RBPP, but Baidoa was always more challenging.

\section{Retention and attrition}

Recruitment has received significant attention since the end of the Cold War, but international analyses invariably focus on the early stages of vetting and selection and ignore retention even though this is key to assessing success. As the experience of the South West State Police in Baidoa, interim capital of South West State (SWS) shows, retention tells us more about the physical and cultural realities at the heart of policing's early phases than anything else. ${ }^{7}$ Thus 600 officers were initially recruited but by February 2017 the number of active officers stood at 547 , which represents an attrition rate of $9 \%$. Although this figure is within the parameters of international standards for security forces in developing states, the underlying factors prompting police desertion reflect the brutally basic nature of emergent police forces.

The main reasons for desertion included dissatisfaction amongst those recruited from areas outside Baidoa, inadequate command structures, and deployment to front-line positions. The RBPP had been founded on the idea of establishing regionally based police in support of the emerging Federal Member States with Baidoa the preferred deployment location for its police. However, political accommodation within the SWS authority meant that the regional government selected the majority of recruits from Lower Shabelle and the remainder from rural areas in Bay and Bakool, i.e., that approximately 200 officers (or one-third of the force) were recruited from locations which were far removed from their area of deployment. The SWS informally promised local authorities in Lower Shabelle that officers from there would be deployed back to their home location, but the promise was not kept, and $50 \%$ of those recruited for Baidoa deserted in the first year. Overall, approximately $90 \%$ of those leaving came from locations outside of Baidoa town.

The combination of negligible support networks and low stipends placed many officers under considerable pressure, but Somali approaches to command and authority structures also played a part (security analyst, Nairobi, 15 April 2019). In Kismayo the police were answerable to the Jubaland authorities whereas in Baidoa they were responsible to police commanders. Meanwhile the federal officers responsible for supervising the regional police provided limited support, attendance measures did not exist, and local authorities did not hold deserters 


\section{Culture Unbound}

Journal of Current Cultural Research

accountable (the named elders responsible for individual recruits in the initial vetting procedure played no role during training or implementation). There were no weapons-management procedures either, so $62 \%$ of the officers who left did so with their government-provided gun, which sold for US $\$ 900-\$ 1200$ or the equivalent of a year's worth of stipend payments. Attrition was then made worse by harsh deployment methods. For example, in February 2017, 88 police were deployed to front-line posts on the outskirts of Baidoa; 64 were posted to Goofgaduud, which lacked basic food, water and medical supplies and was under constant attack from al Shabaab, while 20 were posted to Owdinle village and four to Deynuuney without equipment or sufficient ammunition. Deployed to such posts indefinitely and on an ad-hoc basis, the officers concerned were treated as expendable militiamen acting in support of South West State's claims to statehood and political recognition.

\section{Conclusions}

This analysis of the basic policing programme implemented in Kismayo and Baidoa indicates the ways in which cultural practices can affect, and operate through, a significant social phenomenon. Drawing on RBPP's implementation, it explores the ways in which police development is shaped by culture, power relations and local realities - in this case, clan-based calculations, Somali and donor politics, and physical insecurity. Its discussion of recruitment, stipends and retention emphasises that policing is not only a product of its environment, but also that it shapes or reinforces its development fundamentally.

Focusing on the ways in which local preferences and cultural practices affect social phenomena such as police forces offers a more persuasive explanation of the ways in which prototypical forces develop than approaches emphasising structural variables or ethical standards. It illustrates the energising and relational factors influencing such forces while emphasising that in much of the world policing provision (and a populace's engagement with it) owes little to formal structures and actors and everything to local norms and preferences, informal power networks, legacy issues and contingencies.

Alice Hills is a visiting professor at the universities of Durham and Leeds, where her research on police development in Somalia is funded by the European Commission's Horizon 2020 research and innovation programme. Before joining Durham University as professor of conflict studies, she was professor of conflict and security at the University of Leeds. Prior to that she taught defence studies at the UK's Joint Services Command and Staff College 


\section{Culture Unbound}

\section{Bibliography}

Ahmad, Liban, 2013. "Somalia's Intelligence Services Mimicry", Pan African News Wire, 1 February 2013: http://panafricannews.blogspot.com/2013/02/somalia-intelligence-services-mimicry.html? $\mathrm{m}=0$, (accessed 04/06/14).

AMISOM Police Newsletter, Jan-Mar 2017: http://amisom-au.org/so/amisom-police-newsletter-2017-1/, (accessed 17/09/17).

Bayley, David, 1990: Patterns of Policing: A Comparative International Analysis, New Brunswick, NJ: Rutgers University Press.

Beek, Jan, Göpfert, Mirco, Owen, Olly, and Steinberg, Jonny (eds), 2017: Police in Africa: The Street Level View, London: Hurst.

Bhabhai, Homi, 1994: The Location of Culture, London: Routledge.

Chan, Janet, 1997: Changing Police Culture: Policing in a Multicultural Society, Cambridge: Cambridge University Press.

Cooper-Knock, Sarah, and Owen, Olly, 2015: "Between Vigilantism and Bureaucracy: Improving our Understanding of Police Work in Nigeria and South Africa", Theoretical Criminology, 19: 3, 355-375.

DefenceWeb, 2017: "al-Shabaab Inc", 25 May 2017: http://www.defenceweb. co.za/index.php?option=com_content\&view $=$ article\&id $=47967, \quad$ (accessed 26/01/18).

de Waal, Alex, 2015: The real politics of the Horn of Africa: Money, war and the business of power, Cambridge: Polity.

DFID, 2015: Annual review-Summary sheet: iati.dfid.gov.uk > iati_documents, (accessed 11/09/19).

DFID, 2016: DFID 7772 Justice Sector Development in Somalia: https://www. contractsfinder.service.gov.uk/Notice/1d430cb2-03ff-4039-999f-755114a3dfae, (accessed 04/04/19).

DFID, 2017a: Development Tracker: Re-establishing basic policing in Somalia: https://devtracker.dfid.gov.uk/projects/GB-1-204276, (accessed 04/04/19).

DFID, 2017b: Security \& Justice Programme, 2017. Annual Review-Summary sheet. July: https://devtracker.dfid.gov.uk/projects/GB-1-205069/documents, (accessed 04/04/19).

DFID, 2017c: Project Completion Report, May 2017. Unpublished.

Findlay, Mark and Uglješa Zvekić, 1993: Alternative Policing Styles: Cross-Cultural Perspectives,Deventer, NL: UNICRI/Kluwer.

Gardner, Katy, and Lewis, David, 2015: Anthropology and Development Challenges for the Twenty-First Century, London: Pluto.

Giustozzi, Antonio, and Isaqzadeh, Mohammed, 2013: Policing Afghanistan: The Politics of the Lame Leviathan, London: Hurst.

Grindle, Merilee, 2007: “Good Enough Governance Revisited”, Development Policy Review, 25: 5, 553-574. 


\section{Culture Unbound}

Journal of Current Cultural Research

Gundel, Joakim (2009): "Clans in Somalia: Report on a Lecture by Joakim Gundel", COI Workshop, Vienna, 15 May 2009 (Revised Edition)', 15 December 2009, Austrian Red Cross, Vienna: http://www.ecoi.net/file_upload/90_1261130976_ accord-report-clans-in-somaliarevisededition-20091215.pdf, (accessed $5 / 5 / 11)$.

Home Office, 2019: "Country Policy and Information Note. Somalia: Majority clans and minority groups in south and central Somalia", London: https://assets. publishing.service.gov.uk/government/uploads/system/uploads/attachment_ data/file/773526/Somalia_-_Clans_-_CPIN_V3.0e.pdf, (accessed 4/12/19).

Koper, Christopher, 1995: "Just enough police presence: Reducing crime and disorderly behavior by optimizing patrol time in crime hot spots", Justice Quarterly, 2: 4, 649-672.

Luling, Virginia (2006): "Genealogy as Theory, Genealogy as Tool: Aspects of Somali Clanship," Social Identities, 12: 4, 472-485.

Marenin, Otwin (1985): "Review: Police Performance and State Rule: Control and Autonomy in the Exercise of Coercion", Comparative Politics, 18: 1, 101-122.

OCHA. 2019: Humanitarian Bulletin SOMALIA 1 - 31 July: https://reliefweb.int/ report/somalia/somalia-humanitarian-bulletin-1-31-july-2019-enso, (accessed 19/07/19).

Observatory of Conflict and Violence Prevention (OCVP), 2015a: Kismayo District Conflict and Security Assessment Report, February 2015: http://ocvp. org/docs/2015/2Wave/Kismayo\%20DCSA\%20Report\%20-\%207-5-2015\%20 inf.pdf, (accessed 04/02/16).

OCVP, 2015b: Baidoa District Conflict and Security Assessment Report, July 2015: http://ocvp.org/docs/2015/Wave5/Baidoa\%20DCSA\%202015.pdf, （accessed 04/02/16).

OCVP, 2016: Comparative District Conflict and Security Assessment Report for Kismayo 2015/2016: http://ocvp.org/docs/2015/Wave6/Kismayo\%20 Comparative\%20DCSA_2016.pdf, (accessed 04 /07/17).

Olivier de Sardan, Jean-Pierre, 2005: Anthropology and Development: Understanding Contemporary Social Change, London: Zed.

Peace Direct, 2019: Opportunities for peace in Kismayo, Somalia Insights from local peacebuilders on the causes of violent conflict and the prospects for peace: https:// www.peacedirect.org/wp-content/uploads/2019/05/P861-PD-Somalia-LVPReport_LR-23.05.19.pdf, (accessed 12/08/19).

Riener, Robert, 2015: "Revisiting the Classics: Three Seminal Founders of the Study of Policing: Michael Banton, Jerome Skolnick and Egon Bittner", Policing and Society, 25: 3, 308-327.

Rottenburg, Richard, 2009: Far-fetched facts: a parable of development aid, trans. Allison Brown and Tom Lampert, Cambridge, MA: MIT Press. 


\section{Culture Unbound}

Journal of Current Cultural Research

Reuters, 2019: "Car bomb and all-night hotel siege kill 26 in Somalia's Kismayo", 14 July: http://news.trust.org/item/20190712161322-zczdy/, (accessed 14/08/19).

Sahan, 2015: Report of the Sahan Mission to Baidoa to Assess the Vetting and Selection of Prospective Recruits for the Interim Southwest Authority (ISWA) Police Force, June. Unpublished.

Sahan, 2016: Report of the Sahan Mission to Baidoa to Assess the Second Vetting and Selection Exercise of Prospective Recruits for the South West State (SWS) Police Force, 10 February. Unpublished.

Sahan, 2017: Police Attrition in the South West State Police Feb (Baidoa). Unpublished.

Smith Statement and transcript, 2010. 21 July, 4-5: http://www.iraqinquiry.org. uk/ media/49232/20100721-smith-final.pdf, (accessed 25/09/14).

Somali Affairs, 2019: "Somalia's Al-Shabaab threatens to target Jubbaland leader, politicians", 26 August: http://www.somaliaffairs.com/news/somalias-al-shabaab-threatens-to-target-jubbaland-leader-politicians/, (accessed 28/08/19).

Transparency International, 2019: Conflict at the bottom, 2019: https://www. transparency.org/en/news/conflict-at-the-bottom, (accessed 25/01/20).

UNDP Somalia: Civilian Police. 2019: https://devtracker.dfid.gov.uk/projects/ GB-1-204276, http://www.so.undp.org/content/somalia/en/home/operations/ projects/democratic_governance/Civillian_Police.html, (accessed 13/08/19).

UN Habitat, 2017: Kismayo Urban Profile: https://reliefweb.int/sites/reliefweb.int/ files/resources/Kismayo\%20City\%20Profile.pdf, (accessed 15/08/19).

UNSOM/UNPOL. 2017: Towards a federated police system in Somalia: https:// issat.dcaf.ch/fre/download/131042/2680352/Federated\%20Police\%20System_ revised.pdf, (accessed 17/08/19).

Waddington, P, 1999: "Police (canteen) sub-culture. An appreciation", British Journal of Criminology, 39: 2, 287-309.

World Bank and United Nations Assistance Mission in Somalia (UNSOM), 2017: Federal Republic of Somalia: Security and Justice Sector PER (public expenditure review. Washington DC: World Bank: http://documents.worldbank.org/ curated/en/644671486531571103/pdf/Somalia-SJPER-01302017-Final-Version.pdf, (accessed 17/04/19).

Zhao, Jihong, Matthew Schneider and Quint Thurman, 2002: "The effect of police presence on public fear reduction and satisfaction: A review of the literature", The Justice Professional 15: 3, 273-299.

${ }^{1}$ This work was supported by the European Union's Horizon 2020 research and innovation programme under grant agreement No 653909. Special thanks are due to Sahan which facilitated the research on which 


\section{Culture Unbound}

Journal of Current Cultural Research

this paper is based, and to DFID for its willingness to discuss RBPP. Nevertheless, the views expressed are solely mine; no funding was involved, and academic freedom was assured.

${ }^{2}$ The conventional term 'officer' is used here despite the police being essentially militiamen. Men made up $87 \%$ of Kismayo's first recruit class though the vetting and selection committee adjusted the results of Phase II to ensure that there was $10 \%$ female participation.

${ }^{3}$ Although Sahan's records are unpublished and unverifiable, its methodology was cross-checked against that of OCVP, which is supported by DFID. For OCVP's methodology see, e.g., OCVP 2015a, i [sic]-5.

${ }^{4}$ For a critical development studies perspective on aid projects, see Rottenburg 2009. For development anthropologies, see Olivier de Sardan 2005

${ }^{5}$ This section is based on Sahan 2016.

${ }^{6}$ Steigman's article was published online as "Logistics at the Edge of the Empire: US Army Logistics Trainers in Somalia", Small Wars Journal, 7 February 2018, but was removed hours later.

${ }^{7}$ This section is based on Sahan 2017. 